\title{
CENTRAL AUDITORY PROCESSES PREDICT READING ABILITIES OF CHILDREN WITH DEVELOPMENTAL DYSLEXIA
}

\author{
Monika Lewandowska ${ }^{1}$, Malgorzata Ganc ${ }^{1}$, Elzbieta Wlodarczyk ${ }^{1}$, Andrzej Senderski ${ }^{2}$, \\ David L. McPherson ${ }^{3}$, Dorota Bednarek ${ }^{4}$, Henryk Skarzynski ${ }^{1}$
}

${ }^{1}$ World Hearing Center, Institute of Physiology and Pathology of Hearing, Kajetany, Poland

${ }^{2}$ Children's Memorial Health Institute, Warsaw, Poland

${ }^{3}$ Brigham Young University, Provo, Utah, USA

${ }^{4}$ University of Social Sciences and Humanities, Warsaw, Poland

Corresponding author: Monika Lewandowska, World Hearing Center, Institute of Physiology and Pathology of Hearing, Mokra 17 Str., 05-830 Nadarzyn, Kajetany, Tel +48 2235603 49, Fax: +48 2235603 67,

e-mail: m.lewandowska@ifps.org.pl

\section{Abstract}

Background: In this paper we showed predictive relationships between central auditory processes, phonological abilities, and reading abilities in children diagnosed with developmental dyslexia (DD). Both empirical data and theoretical approaches indicate that central auditory processing deficits may contribute to developmental dyslexia; however, associations between reading and phonological skills and central auditory processes remain unclear.

Material and methods: Exactly 57 children with dyslexia and 40 age- and gender-matched normal reading children performed reading, phonological, and auditory information processing tests, i.e. the Frequency Pattern Test (FPT), Dichotic Digit Test (DDT), and Gap Detection Test (GDT).

Results: Dyslexic children showed parallel reading, phonological, and auditory information processing deficits. Principal component analysis, performed in dyslexic and normal reading children to reduce the data set before exploring the predictors of language skills, revealed three factors: 1) 'Auditory processing', which received high loadings from phonological, FPT, and DDT for the right ear; 2) 'Age and Cognition', including chronological age as well as measures of fluid intelligence and auditory working memory span; and 3) 'Dichotic listening' for the left ear. All three factors together best predicted reading regular words in children diagnosed with DD, while 'Auditory processing' and 'Age and cognition' together explained most of the variance while predicting pseudo-word reading.

Conclusion: The present study indicates that frequency pattern recognition, dichotic listening for the right year, and phonological awareness are strongly interrelated and constitute the most significant predictor of reading abilities in children diagnosed with dyslexia. The results may have important implications for diagnosis and therapy of language disorders.

Key words: developmental dyslexia • central auditory processes • central auditory processing disorders $\bullet$ CAPD

LOS PROCESOS QUE SE DESARROLLAN EN LA PARTE CENTRAL DEL SISTEMA AUDITIVO PERMITEN PREVER LA HABILIDAD DE LECTURA DE LOS NIÑOS CON DISLEXIA DEL DESARROLLO

\section{Resumen}

Introducción: El estudio ha demostrado que en base a los resultados de las pruebas de los procesos centrales de la audición y de habilidades fonológicas es posible prever el nivel de lectura en los niños con dislexia del desarrollo. Tanto los datos empíricos, como y el enfoque teórico existente indican que la dislexia puede ser provocada por los trastornos de los procesos centrales de la audción. Sin embargo, la relación entre la lectura, habilidades fonológicas y trastornos centrales de la audición, queda no del todo aclarada.

Material y métodos: 57 niños con dislexia y 40 niños sin trastornos de lectura, de la misma edad y sexo al grupo exprerimental, han realizado pruebas de lectura, habilidades fonológicas y procesamiento de la información auditiva (Prueba de Identificación de Patrones de Frecuencia, Prueba de Audición por ambas orejas por separado y Prueba de Detección de Pausas).

Resultados: Los niños con dislexia del desarrollo presentan déficits en la lectura, habilidades fonológicas y trastornos centrales de la audición. El análisis de componentes principales, realizado en base a los datos obtenidos en todo el grupo de personas participantes en el estudio, para reducir el número de factores antes de su posterior análisis estadístico, ha revelado tres 
factores: 1) 'Procesamiento de la información auditiva' que consiste en los resultados de las pruebas fonológicas, de Prueba de Identificación de los Patrones de Frecuencia y la Prueba de Audición por ambos oídos por separado- para el oído derecho), 2) 'Edad y funciones cognitivas', que 'carga' la edad cronológica del niño y los resultados de las pruebas de habilidades intelectuales y del rango de la memoria de trabajo auditiva, y también 3) 'Prueba de Audición por ambos oídos por separado'- para el oído izquierdo. En los niños con dislexia del desarrollo, el modelo compuesto de regresión, que comprendía todos los susodichos factores, era el que mejor permitía prever la habilidad de lectura de palabras con sentido, y el 'Procesamiento de la información de la audición y la Edad y funciones cognitivas' juntas eran los mejores para prever los resultados de la prueba de lectura de palabras sin sentido.

Conclusión: El presente estudio demuestra que la identificación de patrones de frecuencia, audición por ambos oídos por separado (resultados para el oído derecho) y las habilidades fonológicas están correlacionadas y constituyen un importante predictor de habilidades de lectura de los niños con la dislexia del desarrollo. Los resultados obtenidos pueden ser relevantes para el proceso de diagnóstico y tratamiento de trastornos de lenguaje.

\title{
ПРОЦЕССЫ, ПРОИСХОДЯЩИЕ В ЦЕНТРАЛЬНОЙ ЧАСТИ СЛУХОВОЙ СИСТЕМЫ, ПОЗВОЛЯЮТ ПРЕДВИДЕТЬ СПОСОБНОСТЬ ЧТЕНИЯ У ДЕТЕЙ С ПРОГРЕССИРУЮЩЕЙ ДИСЛЕКСИЕЙ
}

\section{Изложение}

Введение: В настоящей работе показано, что на основании результатов тестов процессов центрального слухового перерабатывания и фонологических способностей можно предугадать уровень чтения у детей с прогрессирующей дислексией. И эмпирические данные, и существующие теоретические подходы показывают, что причиной дислексии могут являться расстройства процессов центрального слухового перерабатывания. Однако связь между чтением, фонологическими способностями и центральными расстройствами слуха остаются не польностью выясненными.

Материал и методы: 57 детей с дислексией и 40 детей без расстройств чтения, подобранных по возрасту и полу экспериментальной группы, выполнило тесты на чтение, фонологические способности и обработку слуховой информаци (Тест на Узнавание Образцов Частоты, Тест Слушания на Одно Ухо и Тест на Обнаружение Перерывов).

Результаты: у детей с прогрессирующей дислексией выявлено дефициты чтения и фонологических способностей, а также центральные нарушения слуха. Анализ главных составных частей, сделанный на основании данных, полученных во всей группе иследованных детей, чтобы уменьшить количество факторов перед следующим статистическим анализом, показал три факторы: 1) «Обработка слуховой информации», которую создают результаты фонологических тестов, Теста на Узнавание Образцов Частоты и Теста Слушания на одно ухо для правого уха 2) «Возраст и познавательные функции», которые «заряжает» хронологический возраст ребенка и результаты тестов на интеллектуальные способности и объем рабочей слуховой памяти, а также 3) «Слушание на одно ухо» для левого уха. У детей с прогрессирующей дислексией комплексная модель регресии, которая берет во внимание вышеописанные факторы, давала возможность предугадывать, как можно лучше, умение чтения слов со смыслом, а «Обработка слуховой информации» и «Век и познавательные функции» вместе предугадывали результаты теста чтения бессмысленных слов самым лучшим образом.

Заключение: Представленные исследования показывают, что узнавание образцов частоты, слушание на одно ухо (результаты для правого уха) и фонологические способности связаны между собой и являются существенным предиктором умения чтения детей с прогрессирующей дислексией. Полученные результаты могут иметь значение для процесса диагностики и терапии расстройств речи.

\section{PROCESY ZACHODZĄCE W OŚRODKOWEJ CZĘŚCI UKŁADU SŁUCHOWEGO POZWALAJĄ PRZEWIDZIEĆ UMIEJĘTNOŚĆ CZYTANIA U DZIECI Z DYSLEKSJĄ ROZWOJOWA}

\begin{abstract}
Streszczenie
Wstęp: W pracy wykazano, że na podstawie wyników testów ośrodkowych procesów słuchowych i umiejętności fonologicznych można przewidywać poziom czytania u dzieci z dysleksją rozwojową. Zarówno dane empiryczne, jak i istniejące podejścia teoretyczne wskazują, że przyczyną dysleksji mogą być zaburzenia ośrodkowych procesów słuchowych. Związki między czytaniem, umiejętnościami fonologicznymi i ośrodkowymi zaburzeniami słuchu pozostają jednak nie do końca wyjaśnione.
\end{abstract}


Materiał i metody: 57 dzieci z dysleksją i 40 dzieci bez zaburzeń czytania, dopasowanych pod względem wieku i płci do grupy eksperymentalnej, wykonało testy czytania, umiejętności fonologicznych i opracowywania informacji słuchowej (Test Rozpoznawania Wzorców Częstotliwości, Test Słuchania Rozdzielnousznego i Test Wykrywania Przerw).

Wyniki: Dzieci z dysleksją rozwojową wykazały deficyty czytania, umiejętności fonologicznych oraz ośrodkowe zaburzenia słuchu. Analiza składowych głównych, wykonana na danych uzyskanych w całej grupie osób badanych, żeby zredukować liczbę czynników przed dalszą analizą statystyczną, wykazała trzy czynniki: 1) 'Opracowywanie informacji słuchowej', który tworzą wyniki testów fonologicznych, Testu Rozpoznawania Wzorców Częstotliwości oraz Testu Słuchania Rozdzielnousznego dla prawego ucha), 2) 'Wiek i funkcje poznawcze', które 'ładuje' chronologiczny wiek dziecka oraz wyniki testów zdolności intelektualnych i zakresu słuchowej pamięci roboczej, a także 3) 'Słuchanie rozdzielnouszne’ dla lewego ucha. U dzieci z dysleksją rozwojową złożony model regresji, uwzględniający wszystkie w/w czynniki, pozwalał najlepiej przewidywać zdolność czytania słów sensownych, a 'Opracowywanie informacji słuchowej' oraz Wiek i funkcje poznawcze’ łącznie najlepiej przewidywały wyniki testu czytania słów nonsensownych.

Wniosek: Prezentowane badania wskazują, że rozpoznawanie wzorców częstotliwości, słuchanie rozdzielnouszne (wyniki dla prawego ucha) oraz umiejętności fonologiczne są ze sobą skorelowane i stanowią istotny predyktor zdolności czytania dzieci z dysleksją rozwojową. Uzyskane rezultaty mogą mieć znaczenie dla procesu diagnostyki i terapii zaburzeń językowych.

\section{Background}

Developmental dyslexia (DD) is a specific impairment in the development of reading skills which is not caused by lowered intellectual ability, lack of motivation, sensory acuity deficits, or inadequate education [1]. It has been reported that DD may coexist with Central Auditory Processing Disorders (CAPD [2-6]) diagnosed in the absence of peripheral hearing impairment. CAPD include problems with one or more of the following skills: 1) sound localization, 2) auditory discrimination, 3) auditory pattern recognition, 4) temporal aspects of audition, i.e. gap detection and temporal ordering, 5) speech or nonverbal sound perception in the presence of another signal, e.g. noise, and 6) auditory performance with degraded acoustic signals [7].

Many studies on the relationship between language and auditory information processing indicate a temporal deficit in dyslexia [8-17]. About 40 years ago Paula Tallal's research group $[12,15,18]$ found that children with reading difficulties exhibited problems in perception of rapidly changing auditory information, e.g. formant transitions. Since that time persons with DD have been considered as showing deficits in various auditory temporal processing tasks including gap detection $[9-11,19]$ and pattern recognition [5,20-22].

The gap detection test may be done several ways, but the main idea is to use two stimuli (e.g. noises) of fixed duration and a variable gap between them $[10,11]$. In the typical gap detection paradigm a silent period occurs in the center of an ongoing auditory signal so that two stimuli (the one that precedes and the one that follows the gap) activate the same neuronal pool [23]. The minimum gap duration necessary to hear two sounds is usually $2-3 \mathrm{~ms}$ [24]. Existing evidence shows that listeners are able to hear transitions of speech formant frequencies in the range from 0 to $c a .20 \mathrm{~ms}$, so gap detection thresholds greater than $20 \mathrm{~ms}$ may result in speech perception difficulties [18]. Thus, rapid temporal processing of acoustic information is important for the acquisition of speech and language.

Auditory temporal processing is also typically measured using the Frequency pattern test [25]. The task is to report verbally the order of three tones, two of which are of the same frequency and a third which is of a different frequency. The mechanism underlying the frequency patterning was described by Musiek et al. [26,27]. Accordingly, perception of the tonal pattern involves use of the non-language dominant, usually right, hemisphere (the temporal lobe), whereas verbal labeling requires processing by the dominant (usually left) hemisphere. The right hemisphere first processes the frequency pattern and then the information is transferred via the corpus callosum to the left hemisphere for labeling. Therefore, the integrity of both temporal lobes and the corpus callosum are necessary for effective performance on the frequency patterning task.

In addition to an auditory temporal deficit in DD, dichotic listening impairment has also been reported [28-31]. In a typical dichotic listening test subjects are exposed to 2 or more different auditory verbal stimuli simultaneously and asked to repeat aloud all presented sounds. Information presented to the right ear reaches the language areas of the left hemisphere through a direct route, whereas the auditory input to the left ear is initially transferred to the right hemisphere and crosses the corpus callosum to reach the speech areas of the left hemisphere. The right ear advantage (REA), typically observed in a dichotic listening task, is thought to reflect the left hemisphere's representation for language [32].

The results of dichotic listening tasks in persons diagnosed with dyslexia are inconsistent. Some authors have shown a larger than normal REA, with better performance in the right ear and significantly reduced performance in the left ear [30], whereas others [33] have found a left hemisphere dominance in children diagnosed with DD and CAPD but absence of dominance in dyslexia. Helland et al. [34] demonstrated that hemispheric dominance pattern in children with DD was affected by the efficiency of the training received at school. In this study only children who responded to the therapy showed a right ear advantage.

DDT performance may also be modulated by attention $[35,36]$. Directing attention to either the right or the left ear during dichotic listening significantly affects performance in this task. Specifically, the REA observed in a free recall procedure was enhanced when subjects were asked to direct attention to the right ear or reduced when they attended to the left ear $[28,37]$. 
Although auditory processing deficits in dyslexia have been reported in many studies, the relationship between central auditory information processing, reading abilities, and phonological abilities remain rather complicated. On the one hand language problems can coexist with normal central auditory processing, but on the other hand deficits in auditory processing are not always present in language disorders. Some researchers have found no relationships between reading, phonological abilities, and performance on auditory tasks [38], whereas others [39] have been unable to find significant predictive relationships between measures of auditory and language ability.

Despite the aforementioned difficulties in examining the relationship between language and central auditory skills, auditory processing performance has been demonstrated to be a significant predictor for reading performance [40-42]. Nevertheless, it is still unclear which aspects of central auditory processing are associated with reading deficits of children with DD. Therefore, the aim of the present study was to determine the central auditory processes associated with phonological and reading skills in developmental dyslexia and to explain the variance of reading performance in terms of central auditory processes.

\section{Materials and methods}

\section{Participants}

Exactly 57 dyslexic children (17 females, 40 males) with a mean age of 11 years 8 months ( $\mathrm{SD}=12$ months; range 9 years 4 months to 13 years 2 months), recruited from education authorities and dyslexia centers in Warsaw, and 40 control children (15 females and 25 males) with a mean age of 11 years 11 months ( $\mathrm{SD}=13$ months; range 9 years 2 months to 13 years 2 months) participated in the study. The two groups were not significantly different in the chronological age $(t(1,95)=1.27, p>0.05)$. Diagnosis of dyslexia was made by an experienced multidisciplinary team by means of appropriate Polish validated tools. Participants with dyslexia were recruited among children diagnosed and treated by specialists from one of the psychological counseling centers in Warsaw. IQ was measured using the Wechsler Intelligence Scale for Children and their reading and writing performance were assessed using tests from 'Diagnosis of dyslexia' [43]. All participants had normal IQ and obtained scores in both reading and writing tests below the $4^{\text {th }}$ percentile ${ }^{1}$.

All children had nonverbal intelligence within the normal range (verified by the Standard Progressive Matrices - Classic [44]), were right-handed [45], attended school regularly, and had no history of either neuropsychiatric disease or head trauma. They had normal hearing level in both ears, i.e. below $20 \mathrm{~dB}$ for each of the following frequencies: $125,250,500,750,1000,1500,2000,4000$, and $8000 \mathrm{~Hz}$ (screening audiometry) and normal or corrected-to-normal vision. None of the participants had received formal musical education or played musical instruments.

Parents of all children provided written informed consent for participation in this study. The study was approved by the ethics committee at the Institute of Physiology and Pathology of Hearing and conformed to the Declaration of Helsinki for research on humans.

\section{Procedures}

Children with dyslexia were tested individually in a quiet room at the Institute of Physiology and Pathology of Hearing. Two reading tasks, two phonological tasks, and three auditory processing tests, as well as measures of intellectual ability and working memory span, were randomly presented in two ca. 1-h sessions over two days. Control children were tested individually in one or two sessions at their school in Warsaw or at the Institute of Physiology and Pathology of Hearing.

\section{Reading tasks}

Regular word ( $R W$ ) reading. An experimental version of the RW reading test was developed. It consisted of 130 twoand three-syllables words (nouns, verbs, and adjectives). The word list was printed in columns on a single sheet, in lower case letters (Arial, 12-point). All words were presented in their declensional and conjugational forms, as drawn from a third-grade obligatory book. Children were asked to read aloud each word successively as they moved through the list from top to bottom. The number of correctly read words in $60 \mathrm{~s}$ was measured.

Pseudo-word $(P W)$ reading. Children undertook the standardized ' $€$ atysz' test which is a part of the 'Diagnosis of dyslexia' test battery [46]. The task was to successively read aloud a list of 71 artificial words (consisting of one, two, three, or four syllables) printed in 13 verses. The number of correctly read words in $60 \mathrm{~s}$ was measured.

\section{Phonological tasks}

Phonological Skills Scale (PSS, [47]). The scale consists of 56 trials divided into 6 modules: 1 ) auditory word synthesis; 2) auditory word analysis; 3 ) auditory discrimination of two words differing in a single added phoneme (e.g. mak - smak, Eng. poppy - taste); 4) as before except that a phoneme is replaced (e.g. pal - bal, Eng stake - ball); or $5)$ as before except that a phoneme is switched (e.g. kot - kto, Eng. cat - who); and 6) naming of the above-mentioned difference categories.

In the auditory word synthesis module an experimenter pronounced successive phonemes (e.g. $|w|-|a|-|g|$ $-|a|)$ and the task was to recognize a word was formed from these phonemes (e.g. Iwaga/, weight). In the auditory word analysis children were asked to spell the words they had just heard. For example, the word / mapa/ ( a map) was pronounced and the child was instructed to say $/ \mathrm{m} /$ $|a|-|p|-|a|$. In the auditory word discrimination modules participants were provided with word pairs and had to indicate whether these words were identical or different. In the case of two different words children were asked to identify different phonemes. One word from each pair contained an additional, replaced, or switched phoneme

\footnotetext{
1. Information was provided by psychologists who had worked with the children in the counseling center. The results of the tests were not available for ethical reasons and therefore have not been included in the statistical analyses.
} 
Table 1. Means and standard deviations of analyzed variables in dyslexia and control groups as well as $t$-values for between-groups comparisons. Statistically significant differences are marked with asterisks

\begin{tabular}{|c|c|c|c|c|c|}
\hline \multirow[t]{2}{*}{ Variable } & \multicolumn{2}{|c|}{$\begin{array}{c}\text { Dyslexia } \\
(n=57)\end{array}$} & \multicolumn{2}{|c|}{$\begin{array}{c}\text { Control group } \\
(n=40)\end{array}$} & \multirow[t]{2}{*}{$t$-value } \\
\hline & M & SD & M & SD & \\
\hline \multicolumn{6}{|c|}{ Intellectual abilities and working memory span } \\
\hline Raven's Standard Progressive Matrices & 41.07 & 7.33 & 41.98 & 5.97 & 0.64 \\
\hline \multicolumn{6}{|l|}{ Digit Span (WISC-R) } \\
\hline Digits Forward & 5.00 & 1.21 & 5.38 & 1.06 & 1.59 \\
\hline Digits Backward & 4.09 & 1.00 & 4.48 & 1.01 & 1.86 \\
\hline \multicolumn{6}{|l|}{ Reading } \\
\hline Regular words & 45.02 & 20.64 & 57.68 & 18.90 & $3.08^{*}$ \\
\hline Pseudo-words & 27.70 & 12.36 & 40.90 & 9.89 & $5.61^{\star \star}$ \\
\hline \multicolumn{6}{|l|}{ Phonological Skills } \\
\hline Phonological Skills Scale & 72.02 & 6.81 & 85.98 & 8.85 & $8.78^{* \star}$ \\
\hline Phonological Awareness Test & 65.40 & 18.91 & 81.78 & 11.65 & $4.86^{\star \star}$ \\
\hline \multicolumn{6}{|l|}{ Auditory processing } \\
\hline DDT L (free recall) & 66.96 & 16.93 & 78.30 & 10.24 & $3.77^{\star \star}$ \\
\hline DDT R (free recall) & 82.95 & 11.69 & 86.35 & 9.12 & 1.54 \\
\hline DDT L (directed recall) & 69.92 & 17.90 & 81.53 & 9.81 & $3.72^{* * *}$ \\
\hline DDT R (directed recall) & 83.23 & 13.48 & 92.15 & 5.65 & $3.94^{* * *}$ \\
\hline FPT & 64.34 & 17.95 & 79.04 & 9.48 & $4.65^{\star \star}$ \\
\hline GDT & 3.16 & 1.32 & 2.51 & 0.65 & $2.91^{\star}$ \\
\hline
\end{tabular}

${ }^{* *} p<0.01 ;{ }^{* *} p<0.001$. WISC-R - Wechsler Intelligence Scale for Children - Revised; DDT L - Dichotic Digit Test (left ear); DDT R - Dichotic Digit Test (right ear); FPT - Frequency Pattern Test; GDT - Gap Detection Test.

(see examples above). The sixth module concerned naming the type of difference and the task was to indicate the difference (i.e. addition, replacement, or rearrangement). The percentages of correct responses in all modules were calculated.

Phonological Awareness Test (PAT, [48]) comprised four tasks. The first one was to divide a word into syllables and add a syllable ' $k a$ ' before each syllable. For example, children were exposed to the word / rano/ (morning) and asked to say / karal - / kano/. In the second task the experimenter pronounced a given word in code (e.g. each syllable was preceded by ' $k a$ ') and the child had to decipher the word. For example, the correct response to / kapal - /kasek/ should be /pasek/ (a belt). During the last two parts of the test the word coding using ' $k a$ ' was done at the sentence level. Specifically, the third task was to add ' $k a$ ' before each syllable of each word in a sentence. For example, children heard the sentence /Pada deszcz/ (It's raining) and were asked to say $\mid \mathrm{kapa} /$ - $\mid \mathrm{kada} /$ - / kadeszcz/. Finally, the fourth task was to decipher coded words in a sentence, e.g. to say /Mama gotuje obiad/ (Mother is cooking the dinner) in response to the following coded sentence provided by the experimenter: /Kamal - |kamal - /kago/ - |katul - |kajel - |kao/ - |kabiad/.

The percentages of correctly coded syllables as well as correctly recognized deciphered words were analyzed.

\section{Working memory span test}

The Digits Span Test from the Wechsler Intelligence Scale for Children - Revised [49] consisted of two parts in which participants were asked to repeat a series of digits either in the same manner as presented (Digits Forward) or in the reverse order (Digits Backward). In the Digits Forward subtest the shortest row contained 3 and the longest 9 digits, whereas in the Digits Backward subtest the shortest and the longest row comprised 2 and 8 digits respectively. There were two different sequences of digits of the same length. The test was terminated when a child failed to repeat both rows. The number of correctly repeated rows was calculated.

\section{Intellectual abilities test}

Standard Progressive Matrices - Classic (SPM-C, [44]) was made up of 60 multiple choice questions, listed in order of difficulty. In each test item, the task was to identify the missing element that completed a pattern. The test comprised 5 sets of 12 items each, with items within a set becoming increasingly difficult and requiring greater cognitive capacity to encode and analyze the information. All items were presented in black ink on a white background. The number of correct responses was analyzed. 
Table 2. Correlations between age, intelligence, reading, phonological skills, and central auditory processing in children with dyslexia and in control children $(n=97)$

\begin{tabular}{|c|c|c|c|c|c|c|c|c|c|c|c|c|c|c|}
\hline & \multirow{3}{*}{ Age } & \multirow{3}{*}{ SPM-C } & \multirow{2}{*}{\multicolumn{2}{|c|}{ Digit Span }} & \multirow{2}{*}{\multicolumn{2}{|c|}{ Reading }} & \multirow{2}{*}{\multicolumn{2}{|c|}{ Phonology }} & \multicolumn{6}{|c|}{ Auditory processing } \\
\hline & & & & & & & & & \multicolumn{2}{|c|}{$\begin{array}{c}\text { DDT } \\
\text { (free recall) }\end{array}$} & \multicolumn{2}{|c|}{$\begin{array}{c}\text { DDT } \\
\text { (directed } \\
\text { recall) }\end{array}$} & \multirow[t]{2}{*}{ FPT } & \multirow{2}{*}{ GDT } \\
\hline & & & $\begin{array}{c}\text { Digits } \\
\text { Forward }\end{array}$ & $\begin{array}{c}\text { Digits } \\
\text { Backward }\end{array}$ & RW & PW & PSS & РAT & $\mathbf{L}$ & $\mathbf{R}$ & $\mathbf{L}$ & $\mathbf{R}$ & & \\
\hline Age & - & $.48^{\star \star *}$ & $.28^{* *}$ & $.37^{\star * *}$ & $.24^{*}$ & $.21^{*}$ & $.22^{\star}$ & .19 & $.20^{*}$ & .14 & $.21^{\star}$ & .14 & .08 & -.10 \\
\hline SPM-C & & - & $.32^{\star *}$ & $.38^{\star \star *}$ & $.35^{* \star *}$ & $.27^{\star \star}$ & $.36^{\star \star \star}$ & $.31^{\star *}$ & $.26^{*}$ & .12 & .11 & .10 & $.20^{\star}$ & -.19 \\
\hline \multicolumn{15}{|l|}{ Digit Span } \\
\hline Digits Forward & & & - & $.45^{\star * *}$ & $.26^{\star \star}$ & $.29^{* *}$ & $.28^{* *}$ & $.32^{* *}$ & .18 & .05 & $.23^{*}$ & .19 & .17 & -.04 \\
\hline Digits Backward & & & & - & $.42^{* \star *}$ & $.30^{\star \star}$ & $.34^{\star \star}$ & $.30^{\star *}$ & $.27^{\star \star}$ & .18 & $.40^{\star * \star}$ & $.33^{* *}$ & $.23^{*}$ & -.03 \\
\hline \multicolumn{15}{|l|}{ Reading } \\
\hline RW & & & & & - & $.73^{* * *}$ & $.50^{* \star *}$ & $.55^{\star * *}$ & $.28^{\star *}$ & .13 & $.36^{* * *}$ & $.34^{\star *}$ & $.48^{\star * \star}$ & $-.21^{\star}$ \\
\hline PW & & & & & & - & $.50^{\star \star \star}$ & $.56^{\star \star \star}$ & $.28^{* \star}$ & $.23^{*}$ & $.34^{* *}$ & $.40^{\star \star \star}$ & $.58^{\star \star \star}$ & -.16 \\
\hline \multicolumn{15}{|l|}{ Phonology } \\
\hline PSS & & & & & & & - & $.65^{* \star \star}$ & $.30^{* *}$ & $.31^{\star \star}$ & $.39^{\star *}$ & $.51^{\star \star \star}$ & $.60^{* \star \star}$ & $-.37^{\star \star \star}$ \\
\hline PAT & & & & & & & & - & $.23^{*}$ & $.27^{* *}$ & $.23^{*}$ & $.47^{\star \star *}$ & $.58^{\star \star \star}$ & $-.28^{* *}$ \\
\hline \multicolumn{15}{|l|}{ Auditory processing } \\
\hline DDT L (free recall) & & & & & & & & & - & $.24^{\star}$ & $.61^{\star \star}$ & $.36^{\star \star}$ & $.28^{\star *}$ & $-.23^{\star}$ \\
\hline DDT R (free recall) & & & & & & & & & & - & .14 & $.46^{\star \star *}$ & $.36^{\star \star \star}$ & -.19 \\
\hline DDT L (directed recall) & & & & & & & & & & & - & $.42^{\star \star *}$ & $.38^{\star \star \star}$ & -.16 \\
\hline DDT R (directed recall) & & & & & & & & & & & & - & $.56^{\star \star \star}$ & $-.29^{\star \star}$ \\
\hline FPT & & & & & & & & & & & & & - & $-.39^{\star \star \star}$ \\
\hline GDT & & & & & & & & & & & & & & - \\
\hline
\end{tabular}

${ }^{\star} p<.05 ;{ }^{* *} p<.01 ;{ }^{* * *} p<.001$. SPM-C - Raven Standard Progressive Matrices - Classic; RW - Regular Words; PW - Pseudowords; PSS - Phonological Skills Scale; PAT - Phonological Awareness Test; other abbreviations as per Table 1.

Auditory processing tests

The tests were developed as a result of scientific cooperation between the World Hearing Center of Institute of Physiology and Pathology of Hearing (Poland) and Brigham Young University Department of Communication Disorders (USA). All sounds applied in the tests were presented via headphones (Sennheiser HDA 200) at $60 \mathrm{~dB}$ HL using a Creative SB1 100 sound card.

Dichotic Digits Test (DDT, free recall). Children were presented with two different digits in the left ear and two different digits in the right ear simultaneously and were asked to repeat the digits from both ears.

Dichotic Digits Test (DDT, directed recall). Children heard two digits in the left ear and two different digits in the right ear and the task was to report the digits from either the left or right ear.

The digits were monosyllabic and bisyllabic Polish numbers from 1 through 10 matched for duration so that the maximum difference in length between the digits presented to the right and left ear did not exceeded $230 \mathrm{~ms}$. Children were encouraged to guess when they were unsure of a response. There were 40 pairs of digits (20 pairs in the right and 20 in the left ear) in each of the DDT (free recall) and DDT (directed recall) tests. Percentages of correctly reported digits separately from the left and right ear for both of the aforementioned tasks were calculated.

Frequency Pattern Test (FPT). The task was to hear 3 different 180 -ms tones presented bilaterally in a random threechoice sequence and report the order of the sine wave tones (rise/decay time of $10 \mathrm{~ms}$ ), e.g. if the child heard a high tone, low tone, and a third high tone, the reported sequence was high-low-high. The low-frequency tone was $880 \mathrm{~Hz}$, the high tone frequency was $1122 \mathrm{~Hz}$, and the inter-tone interval was $200 \mathrm{~ms}$. Forty sequences were applied. Percentages of correct responses were analyzed.

Gap Detection Test (GDT). The task was to detect a silent gap in a 500-ms bilaterally applied white noise and press a response button when it was present. The initial gap duration was $10 \mathrm{~ms}$ and it was adjusted to the subjects' ongoing performance, i.e. it increased or decreased 
Table 3. Correlations between age, intelligence, reading skills, phonological skills, and central auditory processing in children with dyslexia $(n=57)$

\begin{tabular}{|c|c|c|c|c|c|c|c|c|c|c|c|c|c|c|}
\hline & \multirow{3}{*}{ Age } & \multirow{3}{*}{ SPM-C } & \multirow{2}{*}{\multicolumn{2}{|c|}{ Digit Span }} & \multirow{2}{*}{\multicolumn{2}{|c|}{ Reading }} & \multirow{2}{*}{\multicolumn{2}{|c|}{ Phonology }} & \multicolumn{6}{|c|}{ Auditory processing } \\
\hline & & & & & & & & & \multicolumn{2}{|c|}{$\begin{array}{c}\text { DDT } \\
\text { (free recall) }\end{array}$} & \multicolumn{2}{|c|}{$\begin{array}{c}\text { DDT } \\
\text { (directed } \\
\text { recall) }\end{array}$} & \multirow{2}{*}{ FPT } & \multirow{2}{*}{ GDT } \\
\hline & & & $\begin{array}{l}\text { Digits } \\
\text { Forward }\end{array}$ & $\begin{array}{c}\text { Digits } \\
\text { Backward }\end{array}$ & RW & PW & PSS & PAT & $\mathbf{L}$ & $\mathbf{R}$ & $\mathbf{L}$ & $\mathbf{R}$ & & \\
\hline Age & - & $.52^{\star * *}$ & .20 & $.42^{\star * *}$ & $.28^{*}$ & .08 & .12 & -.01 & .20 & .23 & .21 & .15 & -.09 & -.05 \\
\hline SPM-C & & - & $.35^{* *}$ & $.42^{\star * *}$ & $.40^{* \star}$ & $.30^{*}$ & $.41^{\star *}$ & $.30^{*}$ & $.33^{*}$ & .15 & .13 & .11 & .18 & -.17 \\
\hline \multicolumn{15}{|l|}{ Digit Span } \\
\hline Digits Forward & & & - & $43^{* *}$ & $.32^{*}$ & $.31^{*}$ & .23 & $.30^{*}$ & .20 & .09 & .18 & .17 & .09 & -.04 \\
\hline Digits Backward & & & & - & $.33^{*}$ & .25 & $.36^{\star *}$ & $.27^{\star}$ & $.34^{\star *}$ & .25 & $.41^{\star *}$ & $.36^{\star *}$ & .15 & -.01 \\
\hline \multicolumn{15}{|l|}{ Reading } \\
\hline RW & & & & & - & $.74^{* \star *}$ & $.57^{\star \star *}$ & $.50^{\star \star *}$ & .25 & $.30^{*}$ & $.33^{*}$ & $.34^{\star *}$ & $.45^{\star \star \star}$ & -.09 \\
\hline PW & & & & & & - & $.47^{\star * *}$ & $.43^{* *}$ & .08 & $.43^{* *}$ & .22 & $.30^{*}$ & $.48^{\star * *}$ & -.16 \\
\hline \multicolumn{15}{|l|}{ Phonology } \\
\hline PSS & & & & & & & - & $.64^{\star * *}$ & .17 & $.57^{\star \star *}$ & $.31^{*}$ & $.59^{\star * *}$ & $.62^{* \star *}$ & $-.38^{\star \star}$ \\
\hline PAT & & & & & & & & - & .08 & $.43^{\star \star}$ & .10 & $.44^{\star \star}$ & $.48^{\star * *}$ & -.16 \\
\hline \multicolumn{15}{|l|}{ Auditory processing } \\
\hline DDT L (free recall) & & & & & & & & & - & -.10 & $.62^{* * *}$ & $.32^{*}$ & .14 & -.16 \\
\hline DDT R (free recall) & & & & & & & & & & - & .09 & $.49^{\star \star \star}$ & $.38^{\star *}$ & -.21 \\
\hline DDT L (directed recall) & & & & & & & & & & & & $.35^{\star \star}$ & $.28^{\star}$ & -.11 \\
\hline DDT R (directed recall) & & & & & & & & & & & & - & $.51^{\star \star \star}$ & $-.29^{\star}$ \\
\hline FPT & & & & & & & & & & & & & - & $-.36^{\star \star}$ \\
\hline GDT & & & & & & & & & & & & & & - \\
\hline
\end{tabular}

${ }^{*} p<.05 ;{ }^{* *} p<.01 ;{ }^{* * *} p<.001$. Abbreviations as per Tables 1 and 2.

in 2-ms increments following an incorrect or correct detection respectively. The mean of the most difficult 5 reversals was calculated, i.e. correct gap detections (hits) followed by misses (no reaction to the gap stimuli) or misses followed by hits.

Before each of above-described auditory information processing tests, all participants received a training session.

\section{Results}

Children diagnosed with DD showed significantly poorer performance not only in reading and phonological tasks but also in DDT, FPT, and GDT (Table 1). Dyslexic and control children were not significantly different with respect to chronological age, auditory working memory span, and intellectual ability.

Correlation analyses performed in all subjects and in children with dyslexia revealed strong associations between reading, phonological skills, and auditory processing (Tables 2 and 3). In general, the better that correctly regular words and pseudo-words were read, the better was the performance on phonological and auditory processing tests.
Chronological age, intellectual ability, and auditory working memory correlated significantly with reading, phonological skills, and dichotic listening for the left ear in both the whole studied group and in children with dyslexia.

To reduce the data set before exploring the predictors of reading abilities in DD we conducted a principal component analysis with varimax rotation on the results of phonological, auditory processing, intellectual ability, and working memory span tests as well as on chronological age. Because the analyzed variables were measured on different scales (e.g. percentages, milliseconds) the data was standardized prior to principal component analysis.

The analysis gave a three-factor solution (Table 4 ). The first factor, 'Auditory processing', accounted for $24.82 \%$ of the variance (eigenvalue $=2.98$ ) and received high loadings from phonological tasks and FPT, as well as from DDT for the right ear in both free recall and directed recall procedures. The second factor, 'Age and Cognition', accounted for $18.87 \%$ of the variance (eigenvalue $=2.27$ ) and got high loadings from chronological age, intellectual abilities, and auditory working memory span. The third factor comprises the measures of dichotic listening for the 
Table 4. Principal component analysis showing rotated factor loadings on reading skills, phonological skills, central auditory processing, chronological age, intellectual skills, and working memory span

\begin{tabular}{lccc} 
& \multicolumn{3}{c}{ Factor loadings } \\
\cline { 2 - 4 } & F1: Auditory processing & F2: Age and Cognition & F3: Dichotic listening for left ear \\
\hline FPT & .795 & .062 & .243 \\
\hline PSS & .731 & .323 & .201 \\
\hline PAT & .716 & .333 & .059 \\
\hline DDT R (DR) & .687 & .061 & .402 \\
\hline DDT R (FR) & .622 & .055 & -.067 \\
\hline GDT & -.571 & .017 & -.086 \\
\hline SPM-C & .181 & .0468 \\
\hline Age & .028 & $\mathbf{. 7 3 3}$ & .069 \\
\hline Digits Backward (WISC-R) & .133 & $\mathbf{. 6 5 9}$ & .350 \\
\hline Digits Forward (WISC-R) & .088 & $\mathbf{. 6 5 3}$ & .156 \\
\hline DDT L (DR) & .199 & .146 & $\mathbf{. 8 6 5}$ \\
\hline DDT L (FR) & .131 & .171 & $\mathbf{. 8 2 0}$ \\
\hline
\end{tabular}

DDT R (DR) - Dichotic Digit Test for right ear (directed recall); DDT R (FR) - Dichotic Digit Test for right ear (free recall); DDT L (DR) - Dichotic Digit Test for left ear (directed recall); DDT L (FR) - Dichotic Digit Test for left ear (free recall); WISC-R - Wechsler Intelligence Scale for Children - Revised; other abbreviations as per Tables 1-3.

left ear (free and directed recall) and explained $15.42 \%$ of the variance. Cumulatively, all these factors accounted for $59.12 \%$ of the variance.

Finally, individual factorial coefficients, derived from the factorial weights of the principal component analysis, were used to explore the predictors of reading skills in children with DD (multiple regression models). 'Auditory processing', 'Age and Cognition', and 'Dichotic listening for the left ear' cumulatively accounted for a significant 38\% of the variance in the prediction of regular word reading, whereas 'Auditory processing' and 'Age and Cognition' explained $22 \%$ of the variance while predicting pseudo-words reading. The factors together were better predictors of reading performance than individual factors. The details of regression analysis are presented in Tables 5 and 6.

\section{Discussion}

In the present study we have shown that children with developmental dyslexia have auditory processing deficits (Table 1). We have also found that in the whole studied group, consisting of both dyslexic and control children, their phonological and reading skills correlated strongly with central auditory processes such as frequency pattern recognition, dichotic listening, and gap detection (Table 2). However, reading and phonological processes in dyslexia were significantly associated only with frequency patterning and dichotic listening for the right ear (Table 3 ). Principal component analysis, performed on results from both dyslexic and normal reading children, revealed interesting associations between phonological, cognitive, and auditory processing measures (Table 4). More specifically, phonological skills, frequency pattern recognition, and dichotic listening of digits in the right ear could together be classed as a separate factor - 'Auditory processing' - which accounts for the majority of the variance. Not surprisingly, chronological age, intellectual abilities, and auditory working memory were highly correlated and comprised a second factor, 'Age and cognition'. The third factor comprised DDT results for the left ear. The first two factors together turned out to be the most significant predictors of regular and pseudo-word reading in children with dyslexia (Tables 5 and 6).

The results here are in accordance with the existing literature on central auditory deficits in language-disordered populations $[2,12,20,22,30,31,50]$. Because children with dyslexia and their normal reading peers did not differ significantly in their intellectual abilities and working memory span, we may conclude that specific deficits in dichotic listening and auditory temporal processing occur in children with dyslexia. The stimuli presented in the central auditory tests are first processed in the peripheral and central auditory system after which cognitive functions, such as attention and memory, play a role [23]. Impaired performance on FPT or DDT suggests that the auditory system of the children with reading disorders, in contrast to age-matched controls, may be more immature or underdeveloped.

However, many different factors may affect performance on auditory tests. Deficits in FPT or GDT may well arise from impaired temporal processing, i.e. sequencing abilities, and from more general concentration or working memory problems. Likewise, too many incorrect responses in DDT might result from impaired simultaneous processing or from a more general auditory attention and shortterm memory deficit. Moreover, in the present study children with dyslexia obtained lower scores in the directed recall procedure of DDT compared to their normal reading peers. These results further support the claim of a more general attention deficit in developmental dyslexia. The effect of attention and memory on the performance 
Table 5. Description and significance of multiple regression models in children with dyslexia

\begin{tabular}{|c|c|c|c|c|c|c|c|}
\hline & Criterion & Model & $\mathbf{R}^{2}$ & $\mathbf{F}$ & $\mathbf{d f}_{\text {Reg }}$ & $\mathbf{d f}_{\text {Res }}$ & $p<$ \\
\hline \multirow[t]{13}{*}{ Reading } & Regular words & F1: Auditory processing & .15 & 9.98 & 1 & 55 & .01 \\
\hline & & F2: Age \& cognition & .14 & 9.16 & 1 & 55 & .01 \\
\hline & & F3: Dichotic listening for the left ear & .03 & 1.76 & 1 & 55 & ns \\
\hline & & F1: Auditory processing & .33 & 13.00 & 2 & 54 & .001 \\
\hline & & F2: Age \& cognition & & & & & \\
\hline & & F1: Auditory processing & & & & & \\
\hline & & F2: Age \& cognition & .38 & 11.01 & 3 & 53 & .001 \\
\hline & & F3: Dichotic listening for the left ear & & & & & \\
\hline & Pseudo-words & F1: Auditory processing & .13 & 8.20 & 1 & 55 & .01 \\
\hline & & F2: Age \& cognition & .07 & 3.91 & 1 & 55 & ns \\
\hline & & F3: Dichotic listening for the left ear & .01 & .69 & 1 & 55 & ns \\
\hline & & F1: Auditory processing & ר? & 736 & ? & 51 & 1 \\
\hline & & F2: Age \& cognition & .22 & 1.30 & 2 & 34 & .01 \\
\hline
\end{tabular}

Table 6. Beta coefficients of significant predictors of multiple regression models in children with dyslexia

\begin{tabular}{|c|c|c|c|c|}
\hline Dependent variable & Predictors & Beta & $\mathbf{t}$ & $\mathrm{p}<$ \\
\hline \multicolumn{5}{|l|}{ Reading } \\
\hline \multirow[t]{8}{*}{ Regular words } & F1: Auditory processing & .39 & 3.16 & .01 \\
\hline & F2: Age \& cognition & .38 & 3.03 & .01 \\
\hline & F3: Dichotic listening for the left ear & .18 & 1.33 & ns \\
\hline & F1: Auditory processing & .43 & 3.82 & .001 \\
\hline & F2: Age \& cognition & .42 & 3.70 & .001 \\
\hline & F1: Auditory processing & .47 & 4.27 & .001 \\
\hline & F2: Age \& cognition & .42 & 3.84 & .001 \\
\hline & F3: Dichotic listening for the left ear & .25 & 2.25 & .05 \\
\hline \multirow[t]{5}{*}{ Pseudo-words } & F1: Auditory processing & .36 & 2.86 & .01 \\
\hline & F2: Age \& cognition & .26 & 1.98 & ns \\
\hline & F3: Dichotic listening for the left ear & .11 & .84 & ns \\
\hline & F1: Auditory processing & .39 & 3.19 & .01 \\
\hline & F2: Age \& cognition & .29 & 2.41 & .05 \\
\hline
\end{tabular}

on these central auditory tests has also been demonstrated by other authors, e.g. Sharma et al. [2] who found that auditory attention and memory accounted for more than $20 \%$ of the variance in DDT and FPT scores.

In the DDT, children with dyslexia reported more digits correctly from the right ear than the left for both free and directed recall procedures. This indicates a right ear (left hemisphere) advantage in the processing of verbal material, a typical laterality effect also seen in normal readers [32]. Although this functional asymmetry is also observed elsewhere in persons with dyslexia [31], some authors [33] provide evidence of a left hemispheric dominance in right-handed adults with DD. Lowered scores in DDT in both ears may be accounted for an ineffective transfer between the two hemispheres which results in an enhanced REA effect [51]. In our study, however, bilaterally reduced performance in DDT raises the possibility that uncontrolled factors related to attention may influence the results, especially in free recall tests during which the listener is not instructed how to direct attention. This experimental procedure may lead to increased arousal and less efficient processing [52] which interacts with attentional focus when the listener has to divide attention between the two ears and make decisions about what is heard. 
One of the most influential theories on cognitive causes of DD postulates that it stems from a phonological deficit [53] which may be a consequence of an abnormality in the left temporal lobe $[54,55]$. In our study children diagnosed with dyslexia showed parallel deficits in phonological tasks and DDT as well as the right ear (left hemispheric) advantage for processing of verbal sounds (digits) (see Table 1). Moreover, only digits presented to the right ear (left hemisphere) significantly correlated with the results of phonological tasks and FPT (Table 3). Thus, our study provides some evidence for a phonological deficit in dyslexia which may be related to dysfunction of the left hemisphere.

Our study revealed significant interrelationships between reading and phonological abilities, frequency pattern recognition, and dichotic listening for the right ear, findings which were particularly seen in the whole studied group (see Tables 2 and 4). Moreover, a combination of the results of phonological tests, FPT, and DDT for the right ear was the strongest predictor of regular and pseudoword reading in children diagnosed with DD. Thus, the study indicates that the reading abilities of children with dyslexia are related not only to their phonological awareness but also to temporal patterning and performance in the right ear under dichotic listening conditions. In summary, auditory processing deficits in children diagnosed with dyslexia may well arise from disruption of processes specific to audition, as well as from more global, memory, and attention deficits. More studies are needed to separate underlying sensory versus cognitive bases for disordered reading problems. Electrophysiological measures or neuroimaging techniques (e.g. fMRI) might provide such information.

\section{Conclusions}

Results of the present study indicate that there are multiple factors which determine reading skills in developmental dyslexia. Further, the language abilities of children diagnosed with dyslexia can be predicted on the basis of their performance on phonological tests, their intellectual ability, and their auditory working memory span, as well as on central auditory processes including frequency pattern recognition and dichotic listening for the right ear. Future research is needed to clarify the relationships between phonological and auditory processing as well as their contribution to the linguistic domain. The results here indicate the need to consider different aspects of auditory processing when diagnosing and treating children with language disorders.

\section{Acknowledgments}

This study was supported by the Polish Ministry for Science and Higher Education Grant No. NN403 214939. We thank psychologists from the Psychological and Educational Clinic No. 21 in Warsaw for recruitment and psychological assessment of participants with developmental dyslexia.

\section{References:}

1. ICD-10: The ICD-10 Classification of Mental and Behavioural Disorders: Clinical Description and Diagnostic Guidelines. Geneva: World Health Organization; 2000.

2. Sharma M, Purdy SC, Kelly AS. Comorbidity of auditory processing, language, and reading disorders. J Speech Lang Hear Res, 2009; 52: 706.

3. Rosen S. Auditory processing in dyslexia and specific language impairment: is there a deficit? What is its nature? Does it explain anything? J Phon 2003; 31: 509-27.

4. Van Ingelghem M, Boets B, Van Wieringen A, Onghena P, Ghesquière P, Wouters J. An auditory temporal processing deficit in children with dyslexia. Learn Disabil Chall Teach Instr Ser Stud Paedagog, 2005; 40: 47-63.

5. Bailey PJ, Snowling MJ. Auditory processing and the development of language and literacy. Br Med Bull, 2002; 63: 135-46.

6. Dawes P, Bishop DVM. Psychometric profile of children with auditory processing disorder and children with dyslexia. Arch Dis Child, 2010; 95: 432-36.

7. ASHA: (Central) Auditory Processing Disorders [Technical Report]. Rockville, MD: American Speech-Language-Hearing Association; 2005

8. Murphy CF, Schochat E. Correlations between reading, phonological awareness and auditory temporal processing. Pro Fono, 2009; 21(1): 13-18.

9. Boscariol M, Guimarães CA, Hage SR, Cendes F, Guerreiro MM. Temporal auditory processing: correlation with developmental dyslexia and cortical malformation. Brain Dev, 2011; 33(10): 824-31.
10. Zaidan E, Baran JA. Gaps-in-noise (GIN@) test results in children with and without reading disabilities and phonological processing deficits. Int J Audiol, 2013; 52: 113-23.

11. Musiek FE, Shinn JB, Jirsa R, Bamiou D-E, Baran JA, Zaida E. GIN (Gaps-In-Noise) test performance in subjects with confirmed central auditory nervous system involvement. Ear Hear, 2005; 26: 608-18.

12. Tallal P, Piercy M. Defects of non-verbal auditory perception in children with developmental aphasia. Nature, 1973; 241: 468-69.

13. Szelag E, Skarzynski H, Senderski A, Lewandowska M. Hearing Loss and Auditory Processing Disorders: Clinical and Experimental Perspectives. In: Han S, Pöppel E. (eds). Culture and Neural Frames of Cognition and Communication. Berlin: Springer, 2011; 153-68.

14. Murphy CFB, Schochat E. How auditory temporal processing deficits relate to dyslexia. Braz J Med Biol Res, 2009; 42: 647-54.

15. Tallal P, Miller S, Fitch RH. Neurobiological basis of speech: a case for the preeminence of temporal processing. Ann N Y Acad Sci, 1993; 682: 27-47.

16. Ben-Artzi E, Fostick L, Babkoff H. Deficits in temporal-order judgments in dyslexia: evidence from diotic stimuli differing spectrally and from dichotic stimuli differing only by perceived location. Neuropsychologia, 2005; 43: 714-23.

17. Boets B, Wouters J, van Wieringen A, Ghesquière P. Auditory temporal information processing in preschool children at family risk for dyslexia: Relations with phonological abilities and developing literacy skills. Brain Lang, 2006; 97: 64-79.

18. Fitch RH, Miller S, Tallal P. Neurobiology of speech perception. Annu Rev Neurosci, 1997; 20: 331-53. 
19. Shinn JB, Chermak GD, Musiek FE. GIN (Gaps-In-Noise) Performance in the Pediatric Population. J Am Acad Audiol, 2009; 20: 229-38.

20. King WM, Lombardino LJ, Crandell CC, Leonard CM. Comorbid Auditory Processing Disorder in Developmental Dyslexia. Ear Hear, 2003; 24: 448-56.

21. Banai K, Ahissar M. Auditory Processing Deficits in Dyslexia: Task or Stimulus Related? Cereb Cortex, 2005; 16: 1718-28.

22. Walker KMM, Hall SE, Klein RM, Phillips DP. Development of perceptual correlates of reading performance. Brain Res, 2006; 1124: 126-41.

23. Phillips DP. An introduction to central auditory neuroscience. In: Musiek FE, Chermak GD (eds.), Handbook of (Central) Auditory Processing Disorder. Auditory Neuroscience and Diagnosis. Volume I. San Diego: Plural Publishing Inc.; 2007; 53-87.

24. Phillips DP. Auditory gap detection, perceptual channels, and temporal resolution in speech perception. J Am Acad Audiol, 1999; 10(6): 343-54.

25. Pinheiro ML, Ptacek PH. Reversals in the perception of noise and tone patterns. J Acoust Soc Am, 1971; 49(6): 1778-83.

26. Musiek FE, Pinheiro ML, Wilson DH. Auditory pattern perception in 'split brain' patients. Arch Otolaryngol, 1980; 106(10): 610-12.

27. Bellis TJ. Assessment and Management of Central Auditory Processing Disorders in the Educational Setting. $2^{\text {nd }}$ ed. NY: Thomson Delamar Learning; 2003.

28. Asbjørnsen AE, Helland T, Obrzut JE, Boliek CA. The role of dichotic listening performance and tasks of executive functions in reading impairment: a discriminant function analysis. Child Neuropsychol, 2003; 9(4): 277-88.

29. Simões MB, Schochat E. (Central) auditory processing disorders in individuals with and without dyslexia. Pro Fono, 2010; 22(4): 521-24.

30. Moncrieff DW, Musiek FE. Interaural asymmetries revealed by dichotic listening tests in normal and dyslexic children. J Am Acad Audiol, 2002; 13(8): 428-37.

31. Moncrieff DW, Black JR. Dichotic listening deficits in children with dyslexia. Dyslexia, 2008; 14: 54-75.

32. Kimura D. Speech lateralization in young children as determined by an auditory test. J Comp Physiol Psychol, 1963; 56: 899-902.

33. Iliadou V, Kaprinis S, Kandylis D, Kaprinis GS. Hemispheric laterality assessment with dichotic digits testing in dyslexia and auditory processing disorder. Int J Audiol, 2010; 49: 247-52.

34. Helland T, Asbjørnsen AE, Hushovd AE, Hugdahl K. Dichotic listening and school performance in dyslexia. Dyslexia, 2008; 14: $42-53$.

35. Asbjørnsen AE, Hugdahl K. Attentional effects in dichotic listening. Brain Lang, 1995; 49(3): 189-201.

36. Kinsbourne $M$. The cerebral basis of lateral asymmetries in attention. Acta Psychol (Amst), 1970; 33: 193-201.

37. Hugdahl K, Carlsson G, Eichele T. Age effects in dichotic listening to consonant-vowel syllables: interactions with attention. Dev Neuropsychol, 2001; 20: 445-57.
38. Bretherton L, Holmes VM: The relationship between auditory temporal processing, phonemic awareness, and reading disability. J Exp Child Psychol, 2003; 84: 218-43.

39. Bishop DVM, Carlyton RP, Deeks JM, Bishop SJ: Auditory temporal processing impairment: Neither necessary nor sufficient for causing language impairment in children. J Speech Lang Hear Res, 1999; 42: 1295-310.

40. Bell SM, McCallum RS, Cox EA. Toward a Research-Based Assessment of Dyslexia Using Cognitive Measures to Identify Reading Disabilities. J Learn Disabil, 2003; 36: 505-16.

41. Hulslander J, Talcott J, Witton C, DeFries J, Pennington B, Wadsworth $\mathrm{S}$ et al. Sensory processing, reading, IQ, and attention. J Exp Child Psychol, 2004; 88: 274-95.

42. Witton C, Stein JF, Stoodley CJ, Rosner BS, Talcott JB. Separate influences of acoustic AM and FM sensitivity on the phonological decoding skills of impaired and normal readers. J Cogn Neurosci, 2002; 14: 866-74.

43. Bogdanowicz M, Jaworowska J, Krasowicz-Kupis G, Matczak A, Pelc-Pękala O, Pietras I et al. DYSLEKSJA 3 - Diagnoza dysleksji u uczniów klasy III szkoły podstawowej (DYSLEXIA 3 - diagnosis of dyslexia in the third grade students of the primary school). Warsaw: PTP; 2009.

44. Jaworowska A, Szustrowa T. SPM-C. Standard Progressive Matrices - Classic. Warsaw: Psychological Test Laboratory of the Polish Psychological Association; 2000.

45. Oldfield RC. The assessment and analysis of handedness: The Edinburgh Inventory. Neuropsychologia 1971; 9: 97-113.

46. Bogdanowicz M. Łatysz Test. Warsaw: Psychological Test Laboratory of the Polish Psychological Association; 2002.

47. Kozniewska E, Matuszewski A. Phonological Skills Scale. Warsaw: Methodical Center of Psychological and Pedagogical Support; 2003.

48. Kaja B, Nair R. Phonological Awareness Scale. In: Kaja B, editor. Diagnosis of dyslexia. Bydgoszcz: WSPBYD; 2003; 70-94.

49. Matczak A, Piotrowska A, Ciarkowska W. WISC-R. Wechsler Intelligence Scale for Children - Revised. Warsaw: Psychological Test Laboratory of the Polish Psychological Association; 2008.

50. Martínez JA, Sánchez E. Dichotic listening CV lateralization and developmental dyslexia. J Clin Exp Neuropsychol, 1999; 21: 519-34.

51. Musiek FE, Weihing J. Perspectives on dichotic listening and the corpus callosum. Brain Cogn, 2011; 76: 225-32.

52. Kershner JR, Morton LL. Directed attention dichotic listening in reading disabled children: a test of four models of maladaptive lateralization. Neuropsychologia, 1990; 28(2): 181-98.

53. Liberman IY. Segmentation of the spoken word. Bull Orton Soc, $1977 ; 3:$ 65-77.

54. Heiervang E, Stevenson J, Hugdahl K. Auditory processing in children with dyslexia. J Child Psychol Psychiatry, 2002; 43: 931-38.

55. Temple E, Poldrack RA, Salidis J, Deutsch GK, Tallal P, Merzenich $\mathrm{MM}$ et al. Disrupted neural responses to phonological and orthographic processing in dyslexic children: an fMRI study. Neuroreport, 2001; 12(2): 299-307. 